Research Article

\title{
Total Serum Level of Calcium and Ion Calcium is Lower in Hypotonic Uterine Inertia
}

\section{Kadar Kalsium Serum total dan Ion lebih rendah pada Penderita Inersia Uteri Hipotonik}

\author{
Josef Wattimury, Wiryawan Permadi, Edwin Armawan \\ Department of Obstetrics and Gynecology \\ Faculty of Medicine University of Padjadjaran/ \\ Dr. Hasan Sadikin Hospital \\ Bandung
}

\begin{abstract}
Objectives: To know the correlation between total and ion serum calcium level with the uterine contractility of laboring patient.

Methods: This is a cross-sectional analytic correlative study measuring the strength of correlation of total and ion calcium serum level between groups with hypotonic uterine inertia - and normal labor. Each group consists of 20 subjects who met inclusion criteria and presented to Dr. Hasan Sadikin Hospital in August - September 2012. Statistical analysis was performed by using Eta $(\eta)$ coefficient.

Results: Mean total calcium serum level on hypotonic uterine inertia is $6.66 \mathrm{mg} / \mathrm{dl}$, while mean of total calcium serum level on normal labor is $8.56 \mathrm{mg} / \mathrm{dl}$, with Eta $(\eta)$ correlation coefficient 0.721 . Mean ion calcium serum level on hypotonic uterine inertia is $4.14 \mathrm{mg} / \mathrm{dl}$, while mean of total calcium serum level on normal labor is 4.92 $\mathrm{mg} / \mathrm{dl}$, with Eta $(\eta)$ correlation coefficient 0.802 .
\end{abstract}

Conclusion: Total serum level of calcium and ion calcium in hypotonic uterine inertia is lower than the level of which in normal labor. There is a strong correlation between total and ion serum calcium level with uterine contractility, the Eta ( $\eta$ ) correlation coefficient are 0.721 and 0.802 respectively.

[Indones J Obstet Gynecol 2013; 1-3: 145-8]

Keywords: hypotonic uterine inertia, ion serum calcium level, normal labor, total serum calcium level

\begin{abstract}
Abstrak
Tujuan: Untuk mengetahui hubungan kadar total kalsium serum dan kadar kalsium ion serum dengan kontraktilitas uterus ibu bersalin.

Metode: Penelitian dilakukan dengan metode analitik korelatif dengan rancangan potong silang yang mengukur kekuatan hubungan antara kadar kalsium ion dan kalsium total pada kelompok inersia uteri hipotonik dengan kelompok persalinan normal. Subjek penelitian pada setiap kelompok berjumlah 20 orang yang memenuhi kriteria inklusi dan datang berobat ke RSUP Dr. Hasan Sadikin Bandung pada bulan Agustus - September 2012. Analisis statistik dilakukan dengan koefisien korelasi Eta ( ).
\end{abstract}

Hasil: Rerata kadar kalsium serum total kontraktilitas inersia uteri hipotonik sebesar 6,66 $\mathrm{mg} / \mathrm{dl}$, sedangkan kadar kalsium serum total persalinan normal sebesar 8,56 mg/dl, dengan nilai Koefisien korelasi Eta (ๆ) 0,721. Rerata kadar kalsium serum ion kontraktilitas inersia uteri hipotonik sebesar 4,14 mg/dl, sedangkan kadar kalsium serum ion persalinan normal sebesar 4,92 mg/dl, dengan nilai Koefisien korelasi Eta (ๆ) 0,802.

Kesimpulan: Terdapat hubungan yang kuat antara kadar kalsium serum total dan ion dengan kontraktilitas uterus. Nilai Koefisien korelasi Eta ( ) nya berturut-turut adalah 0.721 dan 0.802. Kadar kalsium serum total dan ion pada penderita inersia uteri hipotonik lebih rendah daripada persalinan normal.

[Maj Obstet Ginekol Indones 2013; 1-3: 145-8]

Kata kunci: inersia uteri hipotonik, kadar kalsium serum ion, kadar kalsium serum total, persalinan normal

Correspondence: Josef Wattimury. Jln. Dago Pojok 47, Bandung. Telepohone: 081395313762. Email:j_wattimury@yahoo.com

\section{INTRODUCTION}

Uterine contractility is one of the most important factor to achieve successful labor. ${ }^{1-3}$ From Annual Obstetric Department Report of Dr. Hasan Sadikin Hospital in 2009 and 2010, the most of Caesarean section indication is failed oxytocin augmentation, by which is a problem of uterine contractility. 4,5

Hypotonic uterine inertia is defined as having uterine contractions less than 180 Montevideo Unit, ${ }^{1,6}$ which is inadequate strength to produce satisfactory progress of labor. As from the litera- tures we know that hypotonic uterine inertia is the cause of $80 \%$ active phase dystocia. ${ }^{6}$

Oxytocin activates the Phospolipase C-Inositol pathways, which opens the calcium channels and increases intracellular calcium levels. ${ }^{6-14}$ And calcium is the only ions in human body that could bind itself to Calmodulin which can activate the Myosin Light Chain Kinases that can trigger the forming of actin-myosin complex in muscle cells which produces muscles contraction. 1,6,7,9,12,13 
From previous studies we knew that more than $50 \%$ Indonesian people has not consumed the minimum daily calcium requirements to prevent bone mineral loss. ${ }^{15}$ This could means that there should be many patients, men and women, who has hypocalcemia due to poor intake. A Calcium ion in the digestive tract binds with Phytic acid will form a salt compound that will not be absorbed in human intestines. Rice is one of the few diets containing Phytic acid ${ }^{16}$, Indonesians are the highest people to consume rice in the world. ${ }^{17}$ So we could also asume that there should be many patients with hypocalcemia due to rich phytic acid daily diet in Indonesia.

No human study has reported the correlation between calcium serum level and uterine contractility in labor. This is seem as an interesting topic, as the result would bring us closer to knowing how calcium serum level influence the contractility during labor.

\section{METHOD}

This is a cross-sectional analytic correlative study, measuring the strength of correlation of total and ion calcium serum level between groups with hypotonic uterine inertia - and normal labor (total 2 groups). Each group consists of 20 subjects with term gestational age, head presentation, single live fetus, not showing any signs of infection, clinically diagnosed as normal labor or hypotonic uterine inertia on active phase of labor, not having any his- tory of hypertension nor kidney or liver disorder before and during pregnancy, and presented to Dr. Hasan Sadikin Hospital in August - September 2012.

$5 \mathrm{ml}$ of blood sample were collected by cubital vein phlebotomy. The blood was stored for 30-45 minutes in vacutainer, to be centrifuged in 3000 rpm thereafter for 15 minutes. The serum were separated in 2 plastic @ $2 \mathrm{cc}$ in each tubes at $-20^{\circ} \mathrm{C}$. Then the serum level of Total calcium and ion calcium were measured by the same machines in Dr. Hasan Sadikin Clinical Laboratory Unit. The results recorded are serum level of total calcium and ion calcium in $\mathrm{mg} / \mathrm{dl}$.

\section{RESULT}

Characteristics of subjects in both groups are restricted according to specific inclusion criterias such as maternal age, parity and gestational age to avoid certain distortion in interpreting the results. Maternal age should be between 20-35 years, party should not exceed 2 previous pregnancies, and a term (37-42 weeks) age of pregnancy.

Table 1 and 2 shows ion calcium serum level of the group with Hypotonic uterine inertia and normal labor. The serum calcium level is significantly lower in the group with hypotonic uterine inertia. Where as Table 2 shows an equally strong correlation between total calcium serum level of the same group individuals as in Table 1 .

Table 1. Correlation between Uterine Contractility and Ion Calcium Serum Level.

\begin{tabular}{|c|c|c|c|c|c|}
\hline & \multicolumn{2}{|c|}{ Serum Calcium Ion (mg/dl) } & \multirow{2}{*}{$\eta$} & \multirow{2}{*}{$p$ value } & \multirow{2}{*}{$\begin{array}{l}\text { Adjusted } \\
\text { p value }\end{array}$} \\
\hline & $\begin{array}{l}\text { hypotonic Uterine } \\
\text { Inertia }(n=20)\end{array}$ & $\begin{array}{l}\text { Normal Labor } \\
\quad(n=20)\end{array}$ & & & \\
\hline Mean & 4.14 & 4.92 & & & \\
\hline Median & 4.13 & 4.87 & & & \\
\hline Range & $3.55-4.77$ & $4.70-5.15$ & & & \\
\hline Std. Dev & 0.39 & 1.39 & 0.802 & $1.78 \times 10^{-8}$ & 0.04875 \\
\hline Var & 0.16 & 0.02 & & & \\
\hline Percentile 25 & 3.75 & 4.81 & & & \\
\hline Percentile 75 & 4.50 & 5.09 & & & \\
\hline
\end{tabular}

Note: $\eta=$ correlation coefficient of eta; $\eta>0.7 \eta<0.9$ (Correlation level strong) 
Table 2. Correlation between Uterine Contractility and Total Calcium Serum Level.

\begin{tabular}{|c|c|c|c|c|c|}
\hline & \multicolumn{2}{|c|}{ Total Serum Calcium (mg/dl) } & \multirow{2}{*}{$\eta$} & \multirow{2}{*}{ p value } & \multirow{2}{*}{$\begin{array}{l}\text { Adjusted } \\
\text { p value }\end{array}$} \\
\hline & $\begin{array}{l}\text { hypotonic Uterine } \\
\text { Inertia }(n=20)\end{array}$ & $\begin{array}{c}\text { Normal Labor } \\
(n=20)\end{array}$ & & & \\
\hline Mean & 6.65 & 8.56 & & & \\
\hline Median & 6.45 & 8.65 & & & \\
\hline Range & $4.40-8.50$ & $7.20-9.40$ & & & \\
\hline Std. Dev & 1.21 & 0.55 & 0.721 & $1.5221 \times 10^{7}$ & 0.0975 \\
\hline Var & 1.46 & 0.30 & & & \\
\hline Percentile 25 & 5.60 & 8.30 & & & \\
\hline Percentile 75 & 7.97 & 9.05 & & & \\
\hline
\end{tabular}

Note: $\eta=$ correlation coefficient of eta; $\eta>0.7 \eta<0.9$ (Correlation level strong)

\section{DISCUSSION}

The two groups of uterine contractions proposed a similar conclusions regarding the correlation between serum calcium and uterine contractility. These conditions are describing that lower total calcium and ion calcium would provoked poor uterine contractility or clinically known as hypotonic uterine inertia, where there are too limited amount of calcium ion that can form significant uterine muscles contraction. ${ }^{18,19}$ A study done by Sylva R, and Noakes DE in 1984 on animal experiment does explain that drug induced hypocalcemia during labor really can provoked a poor uterine contractility. While this kind of experiment on human are not acceptable due to moral issues. This study shows that total calcium serum level and ion calcium serum level are equally have a strong correlation to uterine contractility during labor. Considering the facts that calcium is widely used in human metabolism and normal function, so that a total serum calcium level is important to be noticed on every laboring patient, so we can estimate how does a person's body functions regarding it's total calcium serum level. ${ }^{10-12}$ But specifically an obstetrician is $t$ should always noticed the importance of knowledge that ion serum calcium is closely related to homeostasis and muscles contractility. ${ }^{10-12}$ So if the patient suffers heavy bleeding then it could lead into hypocalcemia and poor uterine contractility later on, of which is not excluded in this study but frankly there were no cases of antepartum bleeding in this study.

This study reports the same strong correlations between total calcium serum levels and ion calcium serum levels towards contractility. From coefficient correlation of Eta $(\eta)$ in this study, we can make a proper prediction (pre-proportionate reduction of error in prediction ${ }^{20}$ by means of squaring the coefficient value that we get. That way we will have an $\eta^{2}$ on the group of ion serum calcium of 0.64 and $\eta^{2}$ at the group of total calcium is 0.52 . So we can say that if we would like to predict a contractility problem using the value of the total calcium serum levels, then the proportionate errors that we are going to receive is reduced as many as 52\%. And if we are trying to predict the same problem using only ion calcium serum levels, then the proportionate errors that we are going to receive is reduced as many as $64 \%$. This is very logic, because ion serum calcium level is the most easy to use calcium in human body. It is also the one that involved directly with haemostasis and muscle contractility in human body physiology. ${ }^{10-12}$

\section{CONCLUSSION}

Serum level of total calcium and ion calcium is strongly correlated with uterine contractions. There area slight advance of using ion calcium serum level on predicting uterine contractility problems comparing the total calcium serum levels. ( $64 \%$ vs $52 \%$ respectively)

\section{REFERENCES}

1. Cunningham FG, Leveno KJ, Bloom SL, Hauth JC, Gilstrap LC, Wenstrom KD. William Obstetrics. Ed 23. New York: McGraw-Hill; 2010: 439-40. 
2. Oxorn H, Forte WR. Ilmu Kebidanan: Patologi dan Fisiologi Persalinan. Ed 1. Yogyakarta: Yayasan Essentia Medika; 2010: 545-57.

3. Stacy S, Uzelac P. Complication of labor and delivery. In: Decherney AH, Nathan L, Goodwin TM, Laufer N, editors. Current diagnosis and treatment. New York: McGraw-Hill; 2007: 432-40.

4. Laporan tahunan 2009 bagian Obstetri dan Ginekologi. Bandung: Bagian Obgyn FK Unpad; 2010: 172.

5. Laporan tahunan 2010 bagian Obstetri dan Ginekologi. Bandung: Bagian Obgyn FK Unpad; 2011: 157.

6. Mose JC, Alamsyah M, Persalinan Lama. Ilmu Kebidanan. Saifuddin AB, Rachimhadhi T, Wiknjosastro GH, Editor, Ed 4. Jakarta: PT Bina Pustaka Sarwono Prawirohardjo; 2010: 562-79.

7. Zeeman GG, Khan-Dawood FS, Dawood MY. Oxytocin and it's receptor in pregnancy and parturition: current concepts and clinical implications. Obstet Gynecol. 1997; 89(5): 87383.

8. Stubbs TM. Oxytocin for labor induction. Clin Obstet Gynecol. 2000; 43: 489-94.

9. Tribe RM. Regulation of human myometrial contractilityduring pregnancy and labour: are calciumhomeostatic pathways important? Uteriine contractility symposium. London: Exp Physiol; 2001; 86 (2): 247-54.

10. Guyton AC, Hall JE. Text Book Of Medical Physiology. $11^{\text {th }}$ ed. Philadelpia: Elsevier; 2006: 92-100.

11. Ganong WF. Buku Ajar Fisiologi Kedokteran. Edisi ke-22. Jakarta: EGC; 2008: 84-7.

12. Sherwood L. Human physiology from cells to systems. $7^{\text {th }}$ ed. USA: Cengage Learning; 2010: 289-98.
13. Wray S, Burdyga T. Sarcoplasmic reticulum function in smooth muscle. 2010; 90: 113-78. Physiol Rev. [Internet]. 2011 [cited 2011 Mar 15] Available from: www.sciencedirect.com

14. Wray S. Insights into the uterus. 2007; 92(4): 621-31. Exp Physiol. [Internet]. 2011 [cited 2011 Mar 15] Available from: www.sciencedirect.com

15. Hartini TNS, Winkvist A, Lindholm L, Stenlund H, Persson V, Nurdiati DS. Nutrient intake and iron status of urban poor and rural poor without access to rice fields are affected by the emerging economic crisis: the case of pregnant Indonesian women. Eur J Clin Nutr. 2003; 57: 654-66.

16. Sediaoetama DA. Ilmu gizi untuk mahasiswa dan profesi di Indonesia. Edisi ke-1. Jakarta: Dian Rakyat; 1989: 94.

17. Lailiyana, Noor N, Suryatni. Buku ajar gizi kesehatan reproduksi. Edisi ke-1. Jakarta: EGC; 2010: 16-29.

18. Hollinshead FK, Hanlon DW, Gilbert RO, Verstegen JP, Krekeler N, Volkmann DH. Calcium, parathyroid hormone, oxytocin and $\mathrm{pH}$ profiles in the whelping bitch. Theriogenology. [Internet]. 2010; 73(9): 1276-83. 2011 [cited 2011 Mar 15] Available from: www.sciencedirect.com

19. Silva R, Noakes DE. The effect of experimentally induced hypocalcaemia on uterine activity at parturition in the ewe. Theriogenology. [Internet]. 1984; 21(4): 607-23. 2011[cited 2011 Mar 15] Available from: www.sciencedirect.com

20. Moye LA. Multiple analyses in clinical trials fundamentals for investigators, $1^{\text {st }}$ Ed. New York: Springer Verlag; 2003: 95. 